Zi r conol ite and baddel eyi te i $n$ an ul tramaf i c sui te from sout her $n$ I ndi a: Early Ordovi ci an carbonat i te-type mel ts associ at ed wi th ext ensi onal col I apse of the Gondwana crust

\begin{tabular}{|l|l|}
\hline 著者 & $\begin{array}{l}\text { Raj esh V. J. , Yokoyana Kazumi , Sant osh M, Ar ai } \\
\text { Shoj i , Oh C. W, K m S. W }\end{array}$ \\
\hline 著者別表示 & 荒井 章司 \\
\hline $\begin{array}{l}\text { j our nal or } \\
\text { publ i cat i on ti tl e }\end{array}$ & Journal of Geol ogy \\
\hline vol une & 114 \\
\hline number & 2 \\
\hline page r ange & $171-188$ \\
\hline year & $2006-03-01$ \\
\hline URL & ht t p: //doi . or g/10. 24517/00011029 \\
\hline
\end{tabular}




\title{
Zirconolite and Baddeleyite in an Ultramafic Suite from Southern India: Early Ordovician Carbonatite-Type Melts Associated with Extensional Collapse of the Gondwana Crust
}

\author{
V. J. Rajesh, K. Yokoyama, ${ }^{1}$ M. Santosh,${ }^{2}$ S. Arai, ${ }^{3}$ C. W. Oh, and S. W. Kim \\ Department of Earth and Environmental Sciences, Basic Science Research Institute, \\ Chonbuk National University, Chonju 561-756, South Korea \\ (e-mail: rajeshvj@chonbuk.ac.kr)
}

\begin{abstract}
A B S T R A C T
We report here the occurrence of rare zirconium-bearing minerals, zirconolite $\left(\mathrm{CaZrTi}_{2} \mathrm{O}_{7}\right)$ and baddeleyite $\left(\mathrm{ZrO}_{2}\right)$, from an unusual ultramafic suite within the Achankovil Shear Zone (ACSZ) in southern India. Zirconolite occurs as inclusions within spinel in phlogopite-graphite spinellite and shows characteristic development of radial cracks. Baddeleyite is commonly observed as an included phase within phlogopite from phlogopite dunite and graphite-spinel glimmerite. The mineral also occurs less commonly within spinel and graphite from graphite-spinel glimmerite. The composition of zirconolite is characterized by an enrichment of $U$ and $T h$ over rare earth elements. Baddeleyite shows abundance of $\mathrm{Zr}$ with minor $\mathrm{Hf}, \mathrm{Ti}$, and $\mathrm{U}$. The mode of occurrence along with the chemical composition of these minerals implies their formation as early-stage crystallization products from a silica-undersaturated melt that was enriched in "carbonatite-phile elements" such as $\mathrm{Ca}, \mathrm{Zr}, \mathrm{Ti}$, and volatiles $\mathrm{CO}_{2}$ and $\mathrm{H}_{2} \mathrm{O}$. We report U-Pb chemical ages from the zirconolite that show a mean of $469 \pm 11 \mathrm{Ma}$. We correlate this age with the timing of emplacement and consolidation of the ultramafic suite within ACSZ, and it is considerably younger than the late NeoproterozoicCambrian ages reported from this zone. Our data suggest early Ordovician carbonatite-type melts emplaced within ACSZ, which we identify as a mantle-rooted zone. We infer that deep-seated extension along the ACSZ probably triggered the generation of such melts, related to the extensional collapse of the orogen following the collisional assembly of the Gondwana supercontinent.
\end{abstract}

Online enhancement: color figure.

\section{Introduction}

Zirconolite $\left(\mathrm{CaZrTi}_{2} \mathrm{O}_{7}\right)$ and baddeleyite $\left(\mathrm{ZrO}_{2}\right)$, the two major Zr-bearing rare accessory minerals, have been reported from several extraterrestrial and terrestrial lithologies. The wide range of rock types that host these minerals includes carbonatites, kimberlites, alkaline intrusions, pegmatites, skarns, potassic lavas, metacarbonates, sapphirinegranulites, lunar rocks, and alluvial and placer deposits (Raber and Haggerty 1979; Bayliss et al. 1989; 2005.

Manuscript received June 21, 2005; accepted October 18,

${ }^{1}$ Department of Geology, National Science Museum, 3-231, Hyakunin-cho, Shinjuku-ku, Tokyo 169-0073, Japan.

${ }^{2}$ Department of Natural Environmental Science, Faculty of Science, Kochi University, Akebono-cho 2-5-1, Kochi 780-8520, Japan.

${ }^{3}$ Graduate School of Natural Science and Technology, Kanazawa University, Kakuma, Kanazawa 920-1192, Japan.
Gieré and Williams 1992; Zakrzewski et al. 1992; Harley 1994; Williams and Gieré 1996; de Hoog and van Bergen 1997, 2000; Bulakh et al. 1998; Bellatreccia et al. 1999; Lumpkin 1999; Della Ventura et al. 2000; Bingen et al. 2001; Stucki et al. 2001; Carlier and Lorand 2003; Tropper et al. 2003). Most occurrences of zirconolite identify the mineral as a late-stage phase crystallizing from alkaline- and/ or silica-undersaturated magmas such as carbonatites and kimberlites (Williams and Gieré 1996). Zirconolite crystallization has also been observed from hydrothermal/metasomatic fluids. Horning and Wörner (1991) described zirconolite-bearing ultrapotassic low-volatile metasomatic veins in a mantle-derived xenolith. Low-degree partial melting in a basaltic magma can also lead to the formation of zirconolite (Harley 1994). Baddeleyite 

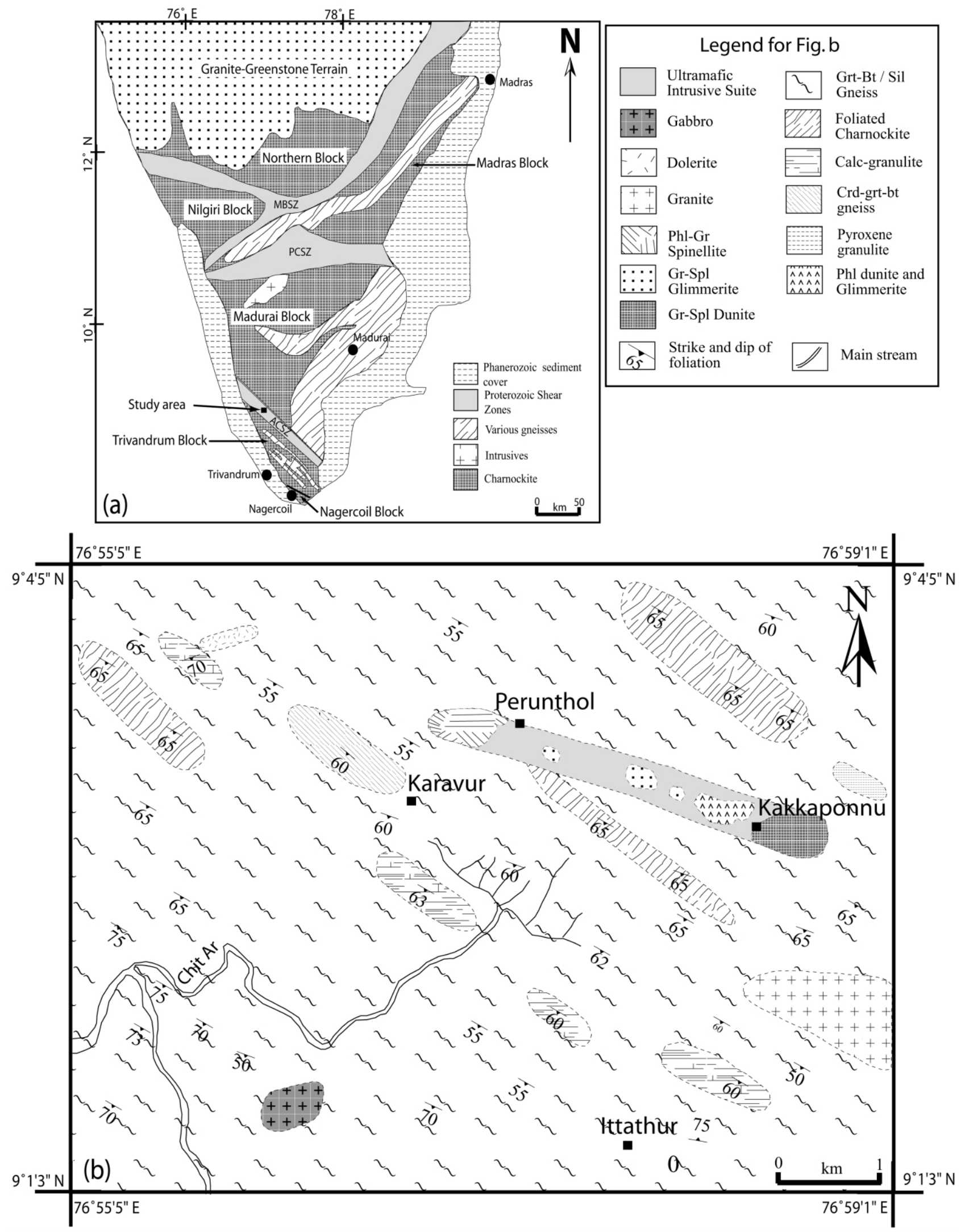
also occurs as late-stage crystallization products in mafic and ultramafic magmas (Heaman and LeCheminant 1993, 2000; Scoates and Chamberlain 1995; Kerschhofer et al. 2000). Zirconolite is an important host for actinide and rare earth elements (REEs) in SYNROC (a material considered for the storage of high level radioactive waste; e.g., Ringwood et al. 1979; Ewing 1999). Baddeleyite is significant as a natural alternate for synthetic $\mathrm{ZrO}_{2}$ in crystalline ceramic materials designed for the safe disposal of high-level nuclear waste from commercial power reactors (Lumpkin 1999).

In this article, we describe an unusual occurrence of zirconolite and baddeleyite from ultramafic intrusive rocks along the Achankovil Shear Zone (ACSZ) in southern India, a major tectonic feature that has prominently figured in discussions on the tectonic and assembly of the Gondwana supercontinent during the late Neoproterozoic-Cambrian period (Windley et al. 1994; Santosh et al. 2005a, $2005 b$, and references therein). We report the petrographic characteristics, mineral chemistry, and isotopic ages and evaluate the results in understanding deep-seated melt/fluid circulation along a transcrustal shear zone during the thermotectonic event attending the birth of the Gondwana supercontinent.

\section{Regional Geological Framework}

The Southern Granulite Terrain (SGT) of south India comprises a collage of various high-grade granulite blocks and major transcrustal shear zones that figure prominently in aeromagnetic maps and satellite images (Drury and Holt 1980). The major Proterozoic units of the SGT include the charnockiteenderbite-gneiss suite of the Madurai Block (MB), a vast supracrustal belt of granulite-grade metapelites in the Trivandrum Block (TB), and the massive charnockites of the Nagercoil Block (NB; Harris et al. 1994; Santosh 1996; fig. 1a). All these terrains experienced widespread and probably multiple tectonothermal events culminating in granulite facies metamorphism during the latest Neoproterozoic (e.g., Bartlett et al. 1998; Santosh et al. 2003, 2005a). Extreme crustal metamorphism at ultrahigh-temperature conditions has been identi- fied from various parts of the MB as well as toward the northern part of the TB proximal to the ACSZ and MB (Raith et al. 1997; Nandakumar and Harley 2000; Morimoto et al. 2004; Sajeev et al. 2004; Tateishi et al. 2004). The NW-SE-trending ACSZ, with a length of $>120 \mathrm{~km}$ and width of $20-50 \mathrm{~km}$, figures as the boundary between the TB and MB. This transcrustal lineament defines prominent magnetic, lithological, and isotopic limits (Santosh 1987; Brandon and Meen 1995; Harris et al. 1996; Braun and Kriegsman 2003; Rajaram et al. 2003), although the kinematics of this structure is debated (Sacks et al. 1997; Rajesh et al. 1998). The major lithological units of ACSZ are deformed and highly migmatized garnet-biotite gneiss, cordierite-spinelorthopyroxene gneisses, garnet-sillimanite-biotite metapelites, garnet-orthopyroxene charnockites, scapolite-bearing calc-silicates, mafic granulites, minor quartzites, and mostly undeformed granites, felsic veins, and pegmatites (Santosh 1987, 1996). Sandiford and Santosh (1991) described unusual kalsilite-hibonite-leucite-bearing feldspathoidal rocks within the ACSZ. Rajesh and Arima (2004) and Rajesh et al. (2004) reported a variety of phlogopite-graphite-dolomite and abundant pure $\mathrm{CO}_{2}$ fluid inclusion-rich ultramafic intrusives within the ACSZ.

Age data on the various lithounits within the ACSZ are available from a number of geochronological studies. Model $\mathrm{Nd}$ isotopic data on various metamorphic units in the ACSZ suggest protolith age in the range of $1.5-1.2 \mathrm{Ga}$, which is significantly younger than the 3.0-2.1-Ga protolith formation ages from the adjacent $\mathrm{TB}$ and $\mathrm{MB}$ (Brandon and Meen 1995; Bartlett et al. 1998; Cenki et al. 2004). Late Neoproterozoic-Cambrian metamorphic ages from the $M B, T B$, and ACSZ include those from single-crystal zircon evaporation methods (530 \pm 21 Ma: Bartlett et al. 1998), electron probe micro analyzer (EPMA) chemical ages (590-520 Ma: Braun and Bröcker 2004; 540-580 Ma: Braun et al. 1998; Santosh et al. 2003, 2005a, 2005b), CHIME monazite ages (527 $\pm 10 \mathrm{Ma}$ : Bindu et al. 1998), and SHRIMP U-Pb zircon ages (525-508 Ma: Collins and Santosh 2004; Santosh et al. 2005a). Sm-Nd whole rock and mineral isochron methods also yield late Pan-African metamorphic ages ranging

Figure 1. $a$, Tectonic setting of Southern Granulite Terrain showing the major granulite blocks, late Proterozoic transcrustal shear zones, and location of the study area. MBSZ, Moyar Bhavani Shear Zone; PCSZ, Palghat Cauvery Shear Zone; ACSZ, Achankovil Shear Zone. $b$, Simplified geological map of the studied area showing extent of the ultramafic intrusive and other lithologies (modified after Rajesh et al. 2004). 
between 558 and $517 \mathrm{Ma}$ (Choudhary et al. 1992; Santosh et al. 1992; Harris et al. 1994). Existing geochronological data indicate Cambrian to Ordovician igneous activity in the ACSZ. An age of $550 \pm 25 \mathrm{Ma}$ is reported for the Chengannoor granite at the western part of the ACSZ from K-Ar analyses of hornblende (Soman et al. 1983). ${ }^{207} \mathrm{~Pb} /{ }^{204} \mathrm{~Pb}$ dating of fluorapatite and monazite from the granites of ACSZ (Braun et al. 1998) provided an emplacement age of $509 \pm 25$ Ma. Recently, Santosh et al. $(2005 b)$ reported an emplacement age in the range of 526-574 Ma from U-Pb electron microprobe ages in zircons and monazites from the $\mathrm{Pa}$ thanapuram granite at the central domain of the ACSZ. Rajesh et al. (2004) reported a mean age of $468 \pm 9 \mathrm{Ma}$ from K-Ar dating of phlogopites in phlogopite dunite and glimmerite within the ACSZ. The emplacement age of various pegmatites in the ACSZ and TB were dated to be Ordovician (478-445 Ma) on the basis of K-Ar biotite and muscovite ages (Soman et al. 1982).

\section{Field Relations, Sample Description, and Petrography}

The ultramafic intrusive suite investigated in this study occurs within the central domain of the ACSZ and is exposed along Kakkaponnu and the neighboring Keezhayam and Perunthol villages (fig. 1b) near Punalur town in the Kollam district of southern Kerala (Rajesh and Arima 2004; Rajesh et al. 2004). The intrusive suite shows marked lithological heterogeneity from very fine-grained graphite-bearing spinel dunite to coarse-grained spinellite with intermediate units like phlogopite dunite, glimmerite, and graphite-spinel glimmerite. These ultramafic rocks are surrounded by intensely deformed granulite facies garnetiferous biotite gneiss, khondalites (migmatized granulite facies metapelites), and charnockites (fig. 1b). In contrast to the surrounding high-grade metamorphic rocks, the ultramafic intrusive suite is undeformed and unmetamorphosed (Rajesh et al. 2004). The vegetation canopy and intense lateritic tropical weathering hinder direct examination of contact relations. The intrusive outcrops as a pipelike body that is $4.5-5 \mathrm{~km}$ long and $\sim 0.30-0.50 \mathrm{~km}$ wide at places. A summary of the megascopic and microscopic features of the various lithologic units in the ultramafic suite is given below (see also Rajesh et al. 2004).

Spinel Dunite. This is the dominant rock unit exposed along the eastern part of the intrusive. The dunite is fine-grained with a jet-black color and is distinguished by abundant glittering graphite flakes. It is an unusual occurrence of graphite-bearing ultramafic rock from this terrain. Along with graphite, phlogopite flakes are also observed in some samples. This peculiar spinel dunite is composed of olivine + spinel + phlogopite \pm graphite \pm ilmenite \pm rutile \pm dolomite \pm calcite \pm magnesite, which is partly serpentinized. Olivine (Mg\# $[\mathrm{Mg} / \mathrm{Mg}+\mathrm{Fe}] \sim 96)$ constitutes $90 \%$ of the modal composition. The spinel $(\mathrm{Mg} \#[\mathrm{Mg} / \mathrm{Mg}+\mathrm{Fe}] \sim 92$; $\mathrm{Cr} \#[\mathrm{Cr} / \mathrm{Al}+\mathrm{Cr}]<0.01)$ is highly aluminous $\left(\mathrm{Al}_{2} \mathrm{O}_{3}\right.$ $\sim 70 \mathrm{wt} \%$ ) and is bluish-violet colored. Calcite and magnesite show spectacular intergrowth textures. Both spinel and olivine host numerous oriented and disoriented high-temperature $\left(\sim 950^{\circ}-1030^{\circ} \mathrm{C}\right)$ melt inclusions. Phlogopite and graphite also occur as inclusions within olivine. Baddeleyite and zirconolite are virtually absent in this rock.

Phlogopite Dunite. The central part of the intrusive contains rock units that are characterized by abundant medium- to coarse-grained phlogopite. The rocks in this domain are phlogopite dunite, glimmerite, and graphite-spinel glimmerite. The light greenish-colored medium-grained phlogopite dunite consists of phlogopite ( 50 vol\%) and serpentinized olivine (30-40 vol\%). Phlogopite occurs as randomly oriented tabular sheets or flaky grains. The mineral assemblage of the phlogopite dunite is olivine + phlogopite + dolomite \pm ilmenite \pm rutile \pm baddeleyite.

Glimmerite. This is a coarse-grained rock dominantly composed of phlogopite mica ( 97 vol\%). The phlogopite contains inclusions of ilmenite and rutile. The mineral assemblage is phlogopite \pm ilmenite \pm rutile.

Graphite-Spinel Glimmerite. This coarse-grained rock consists of clustered spinel inclusions in the matrix of phlogopite and graphite. The mineral paragenesis is phlogopite + spinel + graphite + baddeleyite. Graphite is found as inclusions within the spinel aggregates and also toward the grain periphery in close contact with phlogopite. Individual spinel grains contain abundant melt, $\mathrm{CO}_{2}, \mathrm{C}$, and magnesite inclusions. Zirconolite is virtually absent in this rock type.

Phlogopite-Graphite Spinellite. This is the main rock type recognized in the western extremity of the ultramafic intrusive; it is a coarse-grained rock with specific gravity higher than those of the other units in this suite. This rock is entirely composed of abundant interconnected grains of spinel ( 60 vol\%). The interstices of spinel grains are filled with graphite. At places, flaky phlogopite grains are also present. The mineral assemblage is spinel + graphite + zirconolite \pm phlogopite. Baddeleyite is not detected in any of the studied sections of this 

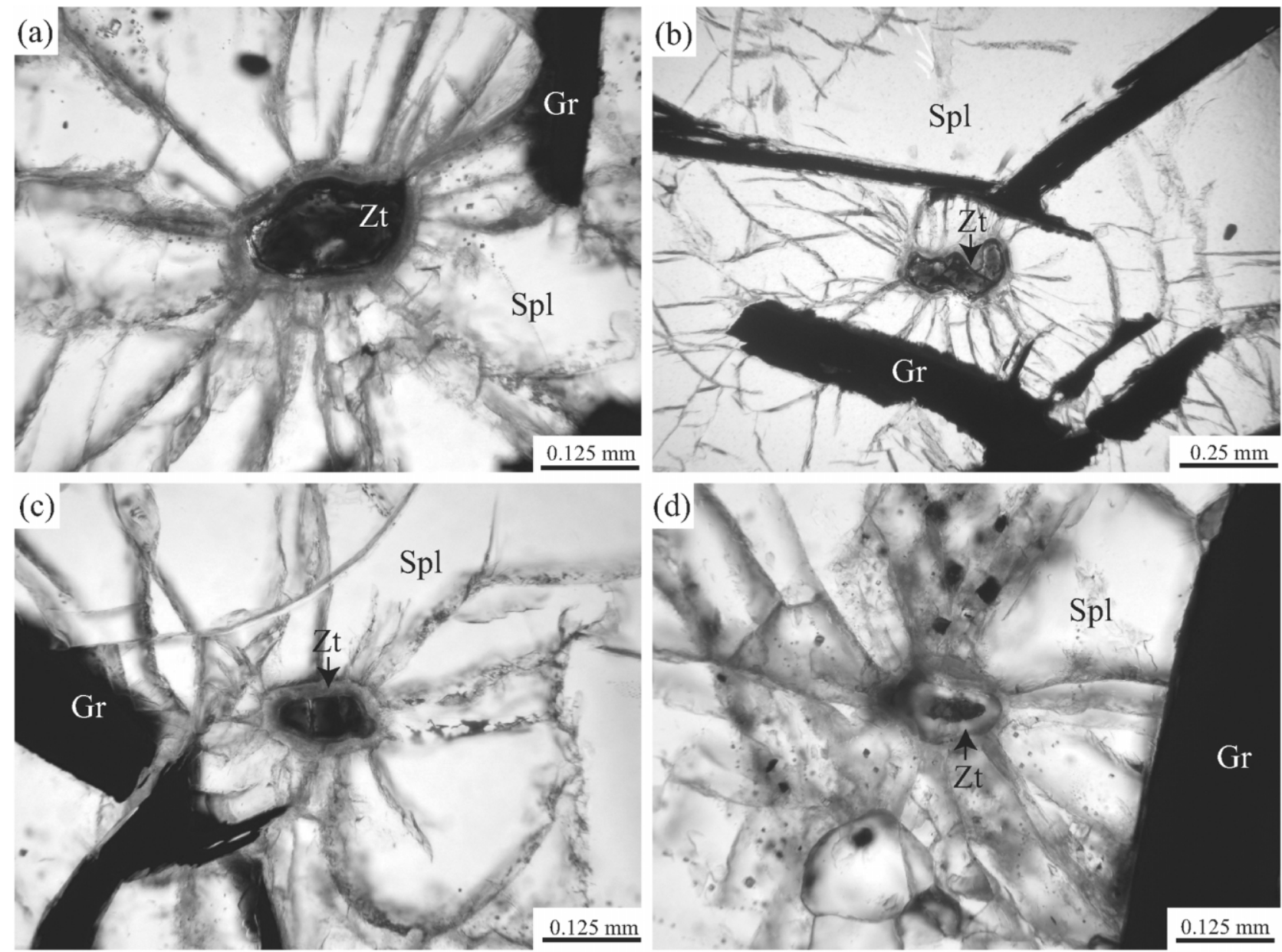

Figure 2. Photomicrographs showing zirconolite $(Z t)$ grains found as inclusions within spinel (Spl) in phlogopitegraphite-spinellite. The zirconolite is deep reddish-brown, similar to the baddelite in figure 3b. Flaky graphites (Gr) can also be observed in the photographs. The well-defined radial cracks surrounding all the zirconolite grains are the characteristic feature of the zirconolite of this study. Also note the abundant inclusions within the spinel $(a, d)$. All the photographs are taken in plane-polarized light.

rock type. Spinel contains abundant melt inclusions, trapped $\mathrm{CO}_{2}$ fluids, $\mathrm{C}$, and magnesite. The spinel $(\mathrm{Mg} \#[\mathrm{Mg} / \mathrm{Mg}+\mathrm{Fe}] \sim 92 ; \mathrm{Cr} \#[\mathrm{Cr} / \mathrm{Al}+\mathrm{Cr}]$ $<0.01)$ is highly aluminous $\left(\mathrm{Al}_{2} \mathrm{O}_{3} 67-70 \mathrm{wt} \%\right)$ and has a composition similar to the spinel observed in the spinel dunite.

\section{Analytical Procedures}

Doubtful grains of zirconolite and baddeleyite were initially identified with the aid of an advanced Olympus optical microscope. The scanning electron microscope activated under the backscattered electron (BSE) mode was then used for the comprehensive petrographical examinations at higher magnifications. The qualitative chemical compo- sition of the zirconolite and baddeleyite grains was determined by means of an automated energydispersive JEOL JSM-5300 scanning electron microprobe and LINK QX2000J system at the Geological Institute, Yokohama National University, Japan. Quantitative chemical analysis was carried out with a JEOL JXA-8800 superprobe fitted with wave length-dispersive spectrometers (WDS) at the National Science Museum, Tokyo, Japan. The operating conditions for the analysis were as follows: $15-20 \mathrm{kV}$ acceleration voltage, $25 \mathrm{nA}$ beam current, $1 \mu \mathrm{m}$ beam diameter; the data were regressed using the ZAF matrix correction program. Data count times of 200-300 s for both peak and background were used for REEs, Hf, $\mathrm{U}$, Th, and $\mathrm{Pb}$, and times of 10-60 s were used for the rest of the elements. 

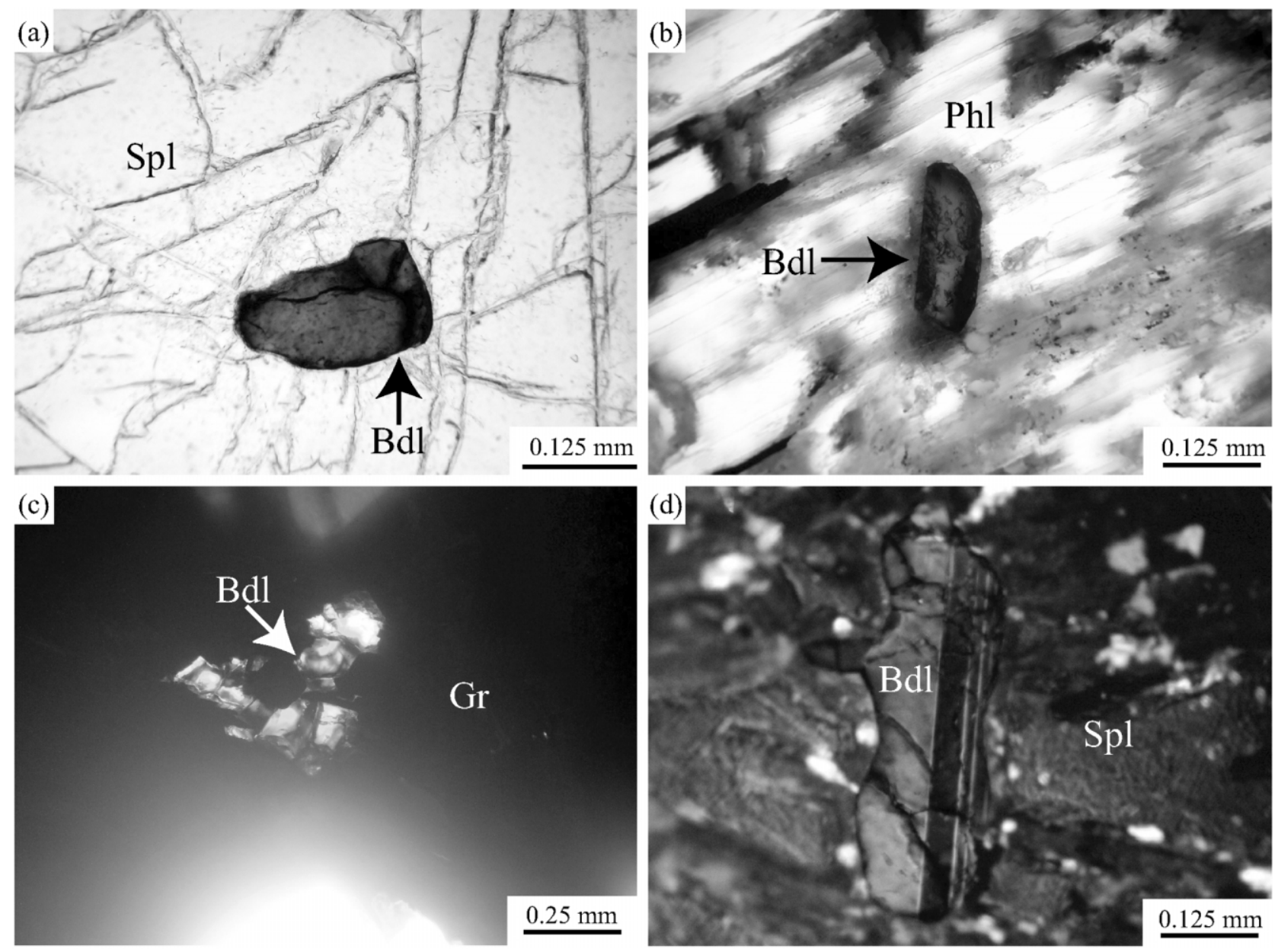

Figure 3. Photomicrographs of baddeleyite $(B d l)$ grains in graphite-spinel-glimmerite. All the photos are in planepolarized light except $d$. Note the characteristic polysynthetic twinning of baddeleyite in $d$. Spl, spinel; Phl, phlogopite; Gr, graphite. A color version of this figure is available in the online edition.

The standard materials for $\mathrm{U}, \mathrm{Th}$, and $\mathrm{Pb}$ were synthesized $\gamma-\mathrm{UO}_{3}, \mathrm{ThO}_{2}$, and natural crocoite $\left(\mathrm{PbCrO}_{4}\right)$, respectively. The natural and synthetic minerals were used for the standardization of other elements. Also $\mathrm{UM} \alpha, \mathrm{ThM} \alpha$, and $\mathrm{PbM} \alpha$ lines were used in the $\mathrm{U}, \mathrm{Th}$, and $\mathrm{Pb}$ analyses, respectively. The spectral interferences of the ThM $\zeta$, YL $\chi$, and $\mathrm{ZrL} \gamma$ lines with the $\mathrm{PbM} \alpha$ line and of the $\mathrm{ThM} \beta$ line with the UM $\alpha$ line were corrected.

In situ dating of accessory minerals such as zircon and monazite by EPMA has been effectively applied to igneous and metamorphic rocks from a variety of terrains (e.g., Suzuki and Adachi 1991, 1994; Suzuki et al. 1991; Montel et al. 1996; Braun et al. 1998; Santosh et al. 2003, 2005a, 2005b). Here we used the same procedure to date the zirconolite grains. Recent studies proved that zirconolite grains provide important tools for the determination of age of emplacement of mafic and ultramafic rocks (Rasmussen and Fletcher 2004). Zirconolite grains in this study were analyzed for age determination using an EPMA with WDS at the National Science Museum, Tokyo, Japan. The theoretical framework of EPMA dating methods and the age calculation procedures adopted in this study follow those of the CHIME method developed by Suzuki et al. (1991). The analytical conditions of the instrument are explained by Yokoyama and Zhou (2002), Biju-Sekhar et al. (2003), and Santosh et al. $(2003,2005 b)$. Due to the nonavailability of zirconolite standard/reference material for age calibration, we used $994 \pm 5$-Ma zircon from Antarctica (analyzed by SHRIMP) as the internal standard material. Apart from negligible shift due to ma- 

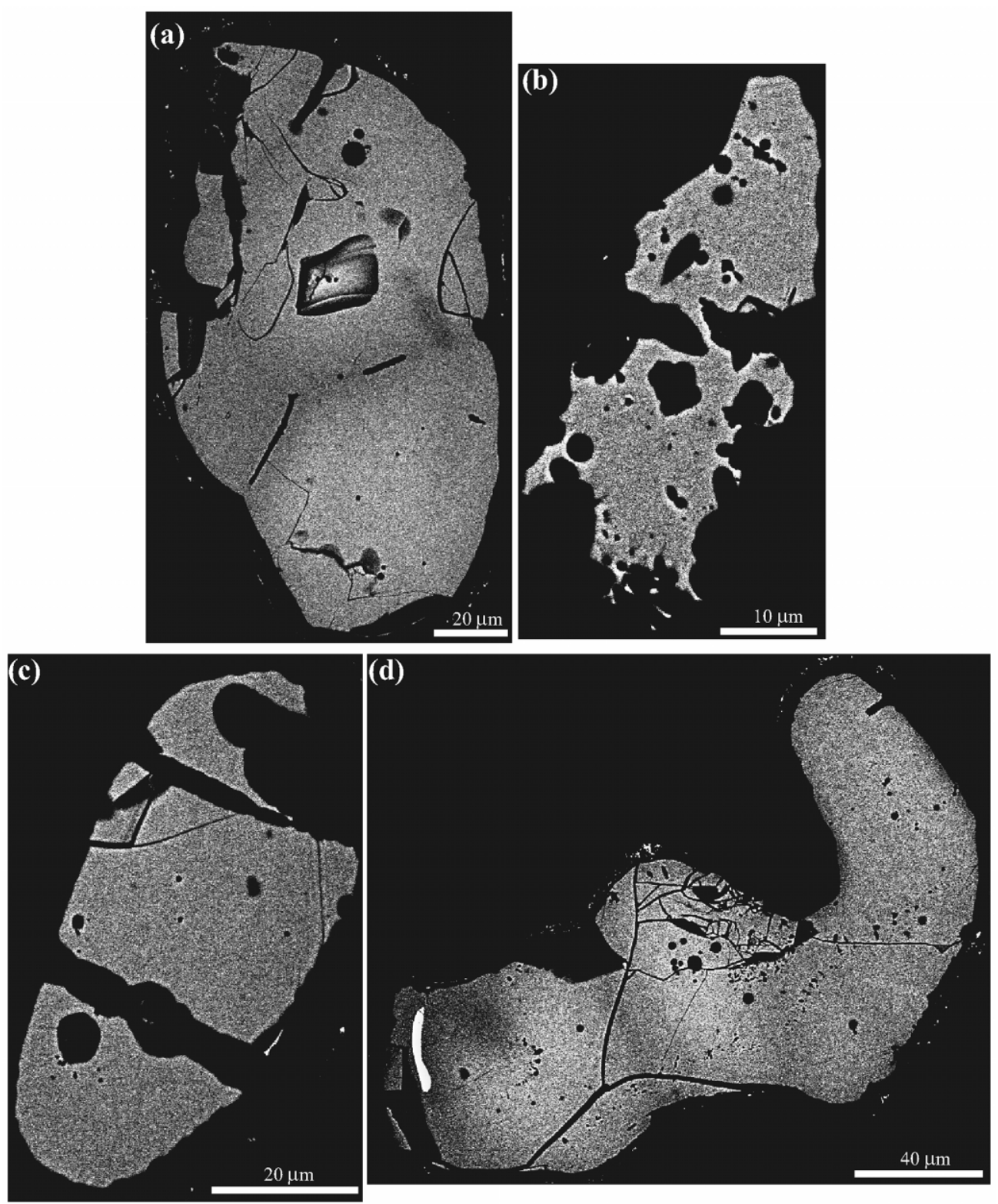

Figure 4. Backscattered electron images of identified grains of zirconolite. Note the absence of magmatic zoning, metamorphic overgrowth, and inclusions within the zirconolite.

chine drift and standard conditions, the data attained from both techniques showed high precision. The error ( $1 \sigma$ confidence level) of age measurements of each zirconolite analysis involves only the instrumental counting statistics and is approximately $3 \%$ at $\mathrm{PbO}=0.05 \mathrm{wt} \%$ to $10 \%$ at $\mathrm{PbO}=0.02 \mathrm{wt} \%$. For age determination, least squares fitting was applied to obtain a linear regression line with the assumption that each data set belongs to a single thermal event. Because of the extremely low contents of $\mathrm{UO}_{2}, \mathrm{ThO}_{2}$, and $\mathrm{PbO}$, we could not obtain dependable and meaningful ages for baddeleyite grains, and they are hence omitted from further age discussions.

\section{Results}

Petrographic Descriptions of Zirconolite and Baddeleyite. Zirconolite. Zirconolite grains are observed only as inclusions within the spinel of 
phlogopite-graphite spinellite. The anhedral and irregular partly metamict zirconolite grains have a uniform translucent reddish-brown color (fig. 2). The grains range in size from 10 to $100 \mu \mathrm{m}$, with an alteration rim at the grain periphery. The most prominent feature of these zirconolite grains is the pronounced development of radial cracks around them (fig. 2), which is to the best of our knowledge the first documentation. These radial cracks are sometimes filled by secondary hydrous aluminium silicate minerals.

Baddeleyite. Baddeleyite occurs within the phlogopite dunite and graphite-spinel glimmerite. The mineral was not observed in the phlogopitegraphite spinellite. Baddeleyite is commonly found as inclusions within phlogopite and graphite, while they are less common within spinel (fig. 3). Baddeleyite grains are usually anhedral, translucent, and reddish-brown in color, with a grain size varying from 65 to $150 \mu \mathrm{m}$. Most of the baddeleyite grains display characteristic polysynthetic twinning (Heaman and LeCheminant 1993). Even though other accessory minerals such as geikielite and rutile are also present in the phlogopite dunite, no sharp grain contact or intergrowth of these accessory phases with baddeleyite was observed in any of the studied sections.

Backscattered electron images of zirconolite (fig. 4) and baddeleyite (fig. 5) clearly bring out their nearly homogeneous nature, with the absence of any magmatic zoning or metamorphic overgrowth patterns. Mutual grain contact or intergrowths with other accessory phases are also lacking. The BSE images also reveal the lack of development of zirconolite rims in baddeleyite and vice versa. Inclusions of zircon grains were also not detected within these two minerals. We thus preclude any possibility of metamorphic reactions involved in the formation of these zirconolite grains. No visible $\mathrm{mineral} / \mathrm{melt} /$ fluid inclusions were noticed in zirconolite and baddeleyite grains. This is in contrast to the abundant occurrence of pure $\mathrm{CO}_{2}$-rich fluid inclusions, high-temperature melt inclusions, and graphite and magnesite solid inclusions in the host spinel grains. All these included phases were recognized by their characteristic laser Raman spectra, and they will be described in a separate article.

Chemical Composition. Zirconolite. Zirconolite has an ideal chemical formula of $\mathrm{CaZrTi}_{2} \mathrm{O}_{7}$ (Borodin et al. 1957), but most natural zirconolite deviates far from the ideal stoichiometry (Gieré 1986; Gieré and Williams 1992; Williams and Gieré 1996 and references therein). The ideal composition can be represented as $\mathrm{ABC}_{2} \mathrm{O}_{7}$, where A represents the $\mathrm{M} 8$ or eightfold coordinated $\mathrm{Ca}$ site, $\mathrm{B}$ denotes the M7 or sevenfold coordinated $\mathrm{Zr}$ site, and the $\mathrm{C}$ site can be in five- or sixfold coordination and be dominated by Ti (M5 or M6; Mazzi and Munno 1983). Several types of chemical substitutions are possible for all three sites. Possible substitution mechanisms are best illustrated by Gieré and Williams (1992) and recently by Zaccarini et al. (2004).

The ACSZ zirconolite deviates far from the ideal chemistry of natural zirconolite. Only $74 \%$ of the $\mathrm{Ca}$ - or M8 site is occupied by $\mathrm{Ca}$, and considerable amounts $(\sim 17 \%)$ of $U$ and $\mathrm{Th}$ and minor amounts $(\sim 8 \%)$ of REE (including Y) substitute for $\mathrm{Ca}$ in this site. Representative chemical compositions of zirconolite grains are listed in table 1 . The studied zirconolite grains contain an average of 10 $\mathrm{wt} \% \mathrm{CaO}, 11 \mathrm{wt} \%(\mathrm{U}+\mathrm{Th}) \mathrm{O}_{2}$, and $2.5 \mathrm{wt} \%$ $(\mathrm{REE}+\mathrm{Y})_{2} \mathrm{O}_{3}$ in its A site. The $\mathrm{Zr}$ site or the M7 site is almost fully occupied by $\mathrm{Zr}(\sim 98 \%)$. An average of $30 \mathrm{wt} \% \mathrm{ZrO}_{2}$ is estimated from the zirconolite grains. In the B site, minor substitution of $\mathrm{Zr}$ by Hf occurs, as deduced from the maximum of $1 \mathrm{wt} \% \mathrm{HfO}_{2}$ present in the zirconolite. The $\mathrm{C}$ site or M5 or M6 site is occupied by $89 \% \mathrm{Ti}$. The $\mathrm{Nb}+\mathrm{Ta}$ substitution for Ti in this site is insignificant because only $1 \%$ of these elements occupy this site. Almost $10 \%$ of this site is occupied by other elements such as $\mathrm{Fe}, \mathrm{Al}, \mathrm{Mg}$, and $\mathrm{Mn}$ replacing $\mathrm{Ti}$ in this site. The zirconolite comprises around $39 \mathrm{wt} \% \mathrm{TiO}_{2}$ and $2.8 \mathrm{wt} \%$ of $\mathrm{FeO}$ in this site. Nearly all of the zirconolite compositional variation falls within the range defined by the following estimated formula:

$$
\begin{aligned}
& \left(\mathrm{Ca}_{0.67-0.72} \mathrm{REE}_{0.05-0.10} \mathrm{~Pb}_{0.01} \mathrm{U}_{0.09-0.14} \mathrm{Th}_{0.05-0.06}\right)_{\Sigma 0.93-0.97} \\
& \left(\mathrm{Zr}_{0.88-0.96} \mathrm{Hf}_{0.01-0.02}\right)_{\Sigma 0.89-0.98} \\
& \left(\mathrm{Ti}_{1.84-1.96} \mathrm{Mg}_{0.01} \mathrm{Fe}_{0.14-0.16} \mathrm{Al}_{0.05-0.06} \mathrm{Nb}_{0.01-0.02}\right)_{\Sigma 2.08-2.17} \mathrm{O}_{7.00}
\end{aligned}
$$

Baddeleyite. The baddeleyite composition is ideally $\mathrm{ZrO}_{2}$. Commonly, the major impurities noticed as trace amounts in natural baddeleyite grains are $\mathrm{Ti}, \mathrm{Fe}$, and Hf. There is no significant compositional variation among the baddeleyites from phlogopite dunite to the graphite-spinel glimmerite. Table 2 presents representative chemical compositions of the baddeleyite grains from both rock units. Most of the analyzed baddeleyite grains contain $\mathrm{ZrO}_{2}(\sim 95-97 \mathrm{wt} \%)$ and $\mathrm{HfO}_{2}(\sim 2.2-3 \mathrm{wt} \%)$, with minor amounts of $\mathrm{UO}_{2}(\sim 0.2-0.3 \mathrm{wt} \%), \mathrm{TiO}_{2}$ $(\sim 0.30-0.65 \mathrm{wt} \%)$, and $\mathrm{FeO}(<0.1 \mathrm{wt} \%)$. Almost all of the analyzed baddeleyite composition lies within 

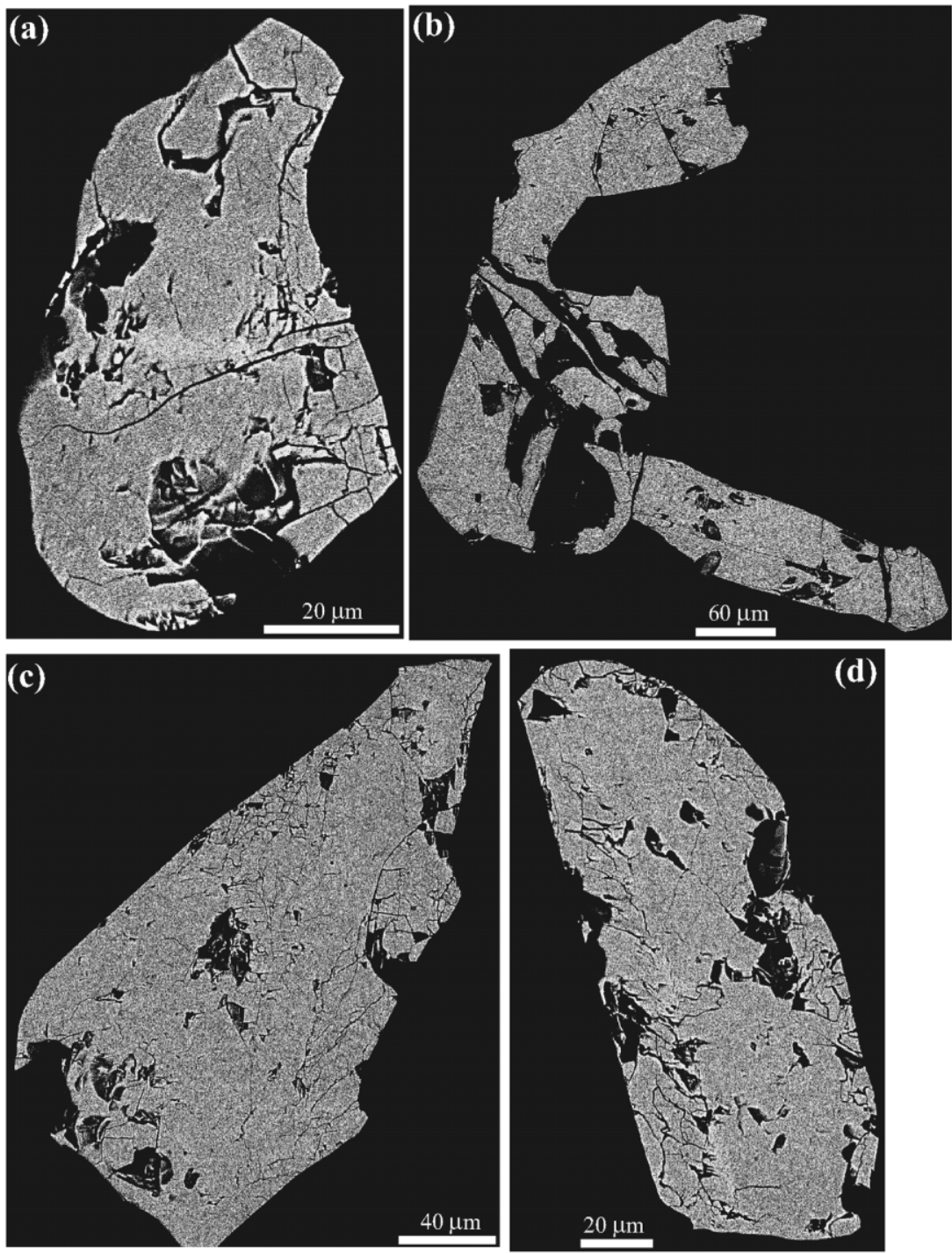

Figure 5. Backscattered electron images of representative baddeleyite grains. Just as in zirconolite, the baddeleyite grains are homogeneous.

the range defined by the following recalculated formula:

$$
\left(\mathrm{Zr}_{0.97-0.98} \mathrm{Hf}_{0.01-0.02} \mathrm{Ti}_{0.01}\right)_{\Sigma 1.00} \mathrm{O}_{2.00} \text {. }
$$

EPMA Chemical Ages. We gathered 21 analyses from three zirconolite grains in the same section of phlogopite-graphite spinellite used for mineral chemistry. The BSE images (figs. 4, 5) of the grains were used to select the analytical points, taking care to avoid domains within and adjacent to metamictized portions of the grains. The analyzed zirconolite grains do not show significant variations in age for their core to rim portions. This further confirms the homogeneous nature of the zirconolite grains, as revealed through the BSE images and chemical analysis. This in turn indicates that the zirconolites might have crystallized during a single thermal event. All three zirconolite grains preserve measurable amounts of $\mathrm{U}-\mathrm{Th}-\mathrm{Pb}$, yielding remarkably consistent age values. Representative EPMA data for U-Th- $\mathrm{Pb}$ analyses of zirconolite grains along with the calculated ages are listed in table 3. In the $\mathrm{PbO}$ versus $\mathrm{ThO}_{2}^{*}$ (sum of the measured $\mathrm{ThO}_{2}$ and an equivalent for the measured $\mathrm{ThO}_{2}$ ) plots, the data points of zirconolite define a linear array (fig. 6). A linear regression through the data points defines an isochron of $469 \pm 11 \mathrm{Ma}$. 
Table 1. Representative Chemical Compositions of Zirconolite in Phlogopite-Graphite Spinellite Determined by Electron Probe Micro Analyzer, by Analysis Number

\begin{tabular}{|c|c|c|c|c|c|c|c|}
\hline & $4^{*}$ & $4^{*}$ & $4^{*}$ & $2^{*}$ & $2^{*}$ & $1^{*}$ & $1^{*}$ \\
\hline $\mathrm{MgO}$ & .09 & .08 & .07 & .08 & .09 & .09 & .08 \\
\hline $\mathrm{Al}_{2} \mathrm{O}_{3}$ & .74 & .75 & .73 & .64 & .65 & .71 & .69 \\
\hline $\mathrm{CaO}$ & 10.29 & 10.53 & 10.52 & 10.42 & 10.23 & 10.00 & 10.54 \\
\hline $\mathrm{TiO}_{2}$ & 39.76 & 38.78 & 38.87 & 40.02 & 38.66 & 41.70 & 39.87 \\
\hline $\mathrm{MnO}$ & .00 & .04 & .01 & .06 & .03 & .02 & .04 \\
\hline $\mathrm{FeO}$ & 2.89 & 2.93 & 2.94 & 2.88 & 2.86 & 2.71 & 2.71 \\
\hline $\mathrm{Y}_{2} \mathrm{O}_{3}$ & 1.27 & 1.24 & 1.13 & .75 & .79 & 1.78 & .98 \\
\hline $\mathrm{ZrO}_{2}$ & 30.91 & 31.12 & 30.67 & 29.41 & 30.33 & 28.90 & 28.98 \\
\hline $\mathrm{Nb}_{2} \mathrm{O}_{5}$ & .83 & .53 & .70 & .38 & .59 & .38 & .44 \\
\hline $\mathrm{La}_{2} \mathrm{O}_{3}$ & .00 & .00 & .00 & .00 & .00 & .00 & .00 \\
\hline $\mathrm{Ce}_{2} \mathrm{O}_{3}$ & .34 & .32 & .47 & .60 & .67 & .51 & .50 \\
\hline $\mathrm{Pr}_{2} \mathrm{O}_{3}$ & .00 & .00 & .20 & .00 & .20 & .26 & .07 \\
\hline $\mathrm{Nd}_{2} \mathrm{O}_{3}$ & .61 & .56 & .55 & .22 & .38 & .66 & .51 \\
\hline $\mathrm{Sm}_{2} \mathrm{O}_{3}$ & .34 & .29 & .25 & .01 & .06 & .16 & .23 \\
\hline $\mathrm{Gd}_{2} \mathrm{O}_{3}$ & .16 & .51 & .39 & .24 & .15 & .06 & .01 \\
\hline $\mathrm{Dy}_{2} \mathrm{O}_{3}$ & .46 & .10 & .38 & .22 & .08 & .29 & .07 \\
\hline $\mathrm{Er}_{2} \mathrm{O}_{3}$ & .09 & .10 & .00 & .17 & .08 & .00 & .15 \\
\hline $\mathrm{HfO}_{2}$ & .98 & .96 & 1.15 & .78 & .91 & .68 & .38 \\
\hline $\mathrm{Ta}_{2} \mathrm{O}_{5}$ & .26 & .17 & .22 & .12 & .14 & .00 & .00 \\
\hline $\mathrm{PbO}$ & .50 & .52 & .59 & .65 & .72 & .54 & .57 \\
\hline $\mathrm{UO}_{2}$ & 6.57 & 6.51 & 6.68 & 9.37 & 9.64 & 7.47 & 7.26 \\
\hline $\mathrm{ThO}_{2}$ & 3.65 & 3.54 & 3.58 & 3.43 & 4.05 & 3.78 & 3.84 \\
\hline Total & 100.74 & 99.58 & 100.10 & 100.45 & 101.31 & 100.70 & 97.92 \\
\hline$(\mathrm{Y}+\mathrm{REE})_{2} \mathrm{O}_{3}$ & 3.26 & 3.12 & 3.36 & 2.22 & 2.41 & 3.71 & 2.50 \\
\hline \multicolumn{8}{|c|}{ Formulas based on 7 atoms of oxygen: } \\
\hline $\mathrm{Ca}$ & .690 & .712 & .711 & 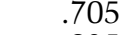 & .696 & .669 & .721 \\
\hline $\mathrm{Y}$ & .043 & .042 & .038 & .025 & .027 & .059 & .033 \\
\hline $\mathrm{La}$ & .000 & .000 & .000 & .000 & .000 & .000 & .000 \\
\hline $\mathrm{Ce}$ & .008 & .007 & .011 & .014 & .015 & .012 & .012 \\
\hline $\operatorname{Pr}$ & .000 & .000 & .005 & .000 & .005 & .006 & .002 \\
\hline $\mathrm{Nd}$ & .014 & .013 & .012 & .005 & .009 & .015 & .012 \\
\hline $\mathrm{Sm}$ & .007 & .006 & .005 & .000 & .001 & .003 & .005 \\
\hline Gd & .003 & .011 & .008 & .005 & .003 & .001 & .000 \\
\hline Dy & -009 & .002 & .008 & .005 & .002 & .006 & .001 \\
\hline Er & .002 & .002 & .000 & .003 & .002 & .000 & .003 \\
\hline $\mathrm{Pb}$ & .008 & .009 & .010 & .011 & .012 & .009 & .010 \\
\hline U & 烈 .091 & -091 & -094 & .132 & .136 & .104 & .103 \\
\hline Th & .052 & .051 & .051 & .049 & .059 & .054 & .056 \\
\hline$\Sigma \mathrm{A}$ & .926 & .946 & .953 & .954 & .967 & .938 & .958 \\
\hline $\mathrm{Zr}$ & .944 & .958 & 943 & .906 & .939 & .880 & .902 \\
\hline $\mathrm{Hf}$ & .017 & .017 & .021 & .014 & .016 & .012 & .007 \\
\hline$\Sigma \mathrm{B}$ & .961 & .975 & .964 & .920 & .955 & .892 & 909 \\
\hline $\mathrm{Ti}$ & 1.871 & 1.841 & 1.843 & 1.902 & 1.847 & 1.958 & 1.915 \\
\hline Mg & .008 & .007 & .007 & .008 & .009 & .008 & .007 \\
\hline $\mathrm{Mn}$ & .000 & .002 & .001 & .003 & .002 & .001 & .002 \\
\hline $\mathrm{Fe}$ & .152 & .155 & .155 & .152 & .152 & .141 & .144 \\
\hline Al & .054 & .056 & .054 & .047 & .049 & .052 & .052 \\
\hline $\mathrm{Nb}$ & .023 & .015 & .020 & .011 & .017 & .011 & .013 \\
\hline $\mathrm{Ta}$ & .004 & .003 & .004 & .002 & .002 & .000 & .000 \\
\hline$\Sigma \mathrm{C}$ & 2.112 & 2.079 & 2.084 & 2.125 & 2.078 & 2.171 & 2.133 \\
\hline Ecations & 3.999 & 4.000 & 4.000 & 3.999 & 4.000 & 4.001 & 4.000 \\
\hline$\Sigma(\mathrm{Y}+\mathrm{REE})$ & .086 & .083 & .087 & .057 & .063 & .102 & .068 \\
\hline
\end{tabular}

\section{Discussion}

Origin of Zirconolite and Baddeleyite. Zirconolite and baddeleyite occurrence described in this study is the first documentation of these minerals from an ultramafic intrusive suite within the ACSZ. Their characteristic occurrence as inclusions within the other major minerals such as spinel, phlogopite, and graphite indicates that they crystallized during the early magmatic phase of the ultramafic suite.

The marked feature of the zirconolite studied here from other reported occurrences of this mineral is the presence of radial cracks surrounding all 
Table 2. Representative Chemical Compositions of Baddeleyite in Graphite-Spinel Glimmerite (139PSG) and Phlogopite Dunite (KKPL) Determined by Electron Probe Micro Analyzer, by Analysis Number

\begin{tabular}{|c|c|c|c|c|c|c|c|c|c|c|c|c|c|c|c|c|}
\hline & 139PSG1 & 139PSG1* & 139PSG1* & 139PSG1 ${ }^{*}$ & 139PSG1-2* & 139PSG1-2* & 139PSG1-3* & 139PSG1-3* & 139PSG1-3* & 139PSG1-3* & 139PSG1-4* & KKPL4 & KKPL4 & KKPL4 & KKPL4 & KKPL4 \\
\hline $\mathrm{TiO}_{2}$ & .44 & .80 & .19 & .38 & .32 & .40 & .44 & .32 & .23 & .51 & .42 & .66 & .33 & .48 & .23 & .55 \\
\hline $\mathrm{FeO}$ & .11 & .04 & .08 & .03 & .11 & .00 & .05 & .04 & .03 & .08 & .15 & .01 & .00 & .02 & .09 & .13 \\
\hline $\mathrm{CaO}$ & .02 & .00 & .03 & .00 & .00 & .00 & .02 & .00 & .05 & .00 & .00 & .00 & .00 & .05 & .00 & .00 \\
\hline $\mathrm{ZrO}_{2}$ & 96.22 & 92.82 & 94.66 & 97.05 & 95.30 & 96.52 & 96.69 & 97.21 & 97.04 & 96.98 & 96.64 & 95.95 & 91.82 & 96.90 & 97.78 & 95.97 \\
\hline $\mathrm{HfO}_{2}$ & 1.67 & 2.23 & 2.66 & 2.60 & 2.19 & 2.43 & 2.13 & 2.07 & 2.28 & 2.23 & 2.38 & 2.58 & 3.14 & 2.89 & 2.76 & 2.66 \\
\hline $\mathrm{UO}_{2}$ & .20 & .34 & .20 & .15 & .22 & .25 & .10 & .00 & .19 & .07 & .12 & .01 & .00 & .01 & .00 & .10 \\
\hline $\mathrm{Y}_{2} \mathrm{O}_{3}$ & .00 & .00 & .02 & .06 & .02 & .00 & .03 & .00 & .00 & . 10 & .07 & .08 & .01 & .00 & .00 & .00 \\
\hline $\mathrm{La}_{2} \mathrm{O}_{3}$ & .00 & .00 & .00 & .00 & .06 & .00 & .00 & .00 & .00 & .00 & .04 & .00 & .00 & .00 & .00 & .00 \\
\hline $\mathrm{Ce}_{2} \mathrm{O}_{3}$ & .04 & .00 & .00 & .00 & .01 & .00 & .10 & .00 & .00 & .00 & .00 & .02 & .09 & .02 & .18 & .01 \\
\hline $\mathrm{Nd}_{2} \mathrm{O}_{3}$ & .04 & .00 & .14 & .00 & .00 & .00 & .00 & .01 & .00 & .09 & .00 & .00 & .00 & .00 & .00 & .00 \\
\hline $\mathrm{Sm}_{2} \mathrm{O}_{3}$ & .00 & .01 & .29 & .00 & .20 & .13 & .00 & .00 & .00 & .00 & .00 & .05 & .07 & .12 & .18 & .04 \\
\hline $\mathrm{Gd}_{2} \mathrm{O}_{3}$ & .02 & .06 & .14 & .00 & .00 & .17 & .25 & .00 & .25 & .00 & .00 & .13 & .00 & .13 & .21 & .19 \\
\hline \multirow{2}{*}{\multicolumn{17}{|c|}{ Formulas based on 2 atoms of oxygen: }} \\
\hline & & & & & & & & & & & & & & & & \\
\hline $\mathrm{Ti}$ & .007 & .013 & .003 & .006 & .005 & .006 & .007 & .005 & .004 & .008 & .007 & .010 & .005 & .007 & .004 & .009 \\
\hline $\mathrm{Fe}$ & .002 & .001 & .001 & .000 & .002 & .000 & .001 & .001 & .000 & .001 & .003 & .000 & .000 & . 000 & .001 & .002 \\
\hline $\mathrm{Ca}$ & .000 & .000 & .001 & .000 & .000 & .000 & .000 & .000 & .001 & .000 & .000 & .000 & .000 & .001 & .000 & .000 \\
\hline $\mathrm{Zr}$ & .981 & .971 & .976 & .977 & .978 & .977 & .977 & .982 & .980 & .977 & .977 & .973 & .974 & .973 & .977 & .973 \\
\hline $\mathrm{Hf}$ & .010 & .014 & .016 & .015 & .013 & .014 & .013 & .012 & .013 & .013 & .014 & .015 & .020 & 017 & .016 & .016 \\
\hline $\mathrm{U}$ & .001 & .002 & .001 & .001 & .001 & .001 & .000 & .000 & .001 & . 000 & .001 & .000 & .000 & . 000 & .000 & .000 \\
\hline $\mathrm{Y}$ & .000 & . 000 & .000 & .001 & .000 & .000 & .000 & .000 & .000 & .001 & .001 & .001 & .000 & .000 & .000 & .000 \\
\hline $\mathrm{La}$ & .000 & .000 & .000 & .000 & .000 & .000 & .000 & .000 & .000 & .000 & .000 & .000 & .000 & .000 & .000 & .000 \\
\hline $\mathrm{Ce}$ & .000 & .000 & .000 & .000 & .000 & .000 & .001 & .000 & .000 & .000 & . 000 & .000 & .001 & .000 & .001 & .000 \\
\hline $\mathrm{Nd}$ & .000 & .000 & .001 & .000 & .000 & . 000 & .000 & .000 & .000 & .001 & . 000 & .000 & .000 & . 000 & .000 & .000 \\
\hline $\mathrm{Sm}$ & .000 & .000 & .002 & .000 & .001 & .001 & .000 & .000 & . 000 & .000 & . 000 & .000 & .001 & .001 & .001 & .000 \\
\hline Gd & .000 & .000 & .001 & .000 & .000 & .001 & .002 & .000 & .002 & .000 & .000 & .001 & .000 & .001 & .001 & .001 \\
\hline Lcations & 1.001 & 1.001 & 1.002 & 1.000 & 1.000 & 1.000 & 1.001 & 1.000 & 1.001 & 1.001 & 1.003 & 1.000 & 1.001 & 1.000 & 1.001 & 1.001 \\
\hline
\end{tabular}


Table 3. Electron Microprobe Analyses of Zirconolite Grains in Phlogopite-Graphite Spinellite (139SG1)

\begin{tabular}{lccccc}
\hline Grain & $\mathrm{UO}_{2}$ & $\mathrm{ThO}_{2}$ & $\mathrm{PbO}$ & $\mathrm{ThO}_{2}^{*}$ & Age $(\mathrm{Ma})$ \\
\hline $1^{*}$ & 7.97 & 4.03 & .596 & 30.306 & 465 \\
$1^{*}$ & 7.90 & 4.06 & .584 & 30.091 & 459 \\
$1^{*}$ & 7.63 & 4.09 & .572 & 29.236 & 462 \\
$1^{*}$ & 7.00 & 3.14 & .498 & 26.196 & 449 \\
$1^{*}$ & 7.07 & 2.69 & .496 & 25.951 & 452 \\
$1^{*}$ & 7.58 & 3.94 & .559 & 28.891 & 458 \\
$1^{*}$ & 7.25 & 3.38 & .527 & 27.254 & 457 \\
$2^{*}$ & 9.73 & 3.65 & .703 & 35.724 & 465 \\
$2^{*}$ & 9.86 & 3.90 & .712 & 36.376 & 462 \\
$2^{*}$ & 9.81 & 3.93 & .704 & 36.231 & 459 \\
$2^{*}$ & 9.71 & 3.95 & .709 & 35.937 & 466 \\
$2^{*}$ & 10.26 & 4.24 & .769 & 38.078 & 477 \\
$2^{*}$ & 9.55 & 3.77 & .705 & 35.260 & 473 \\
$2^{*}$ & 9.63 & 4.42 & .737 & 36.208 & 481 \\
$2^{*}$ & 8.41 & 2.60 & .595 & 30.306 & 464 \\
$2^{*}$ & 9.19 & 4.43 & .697 & 34.750 & 474 \\
$2^{*}$ & 9.46 & 3.92 & .705 & 35.106 & 475 \\
$4^{*}$ & 6.79 & 3.73 & .539 & 26.146 & 487 \\
$4^{*}$ & 6.19 & 3.61 & .492 & 24.049 & 483 \\
$4^{*}$ & 6.39 & 3.61 & .509 & 24.715 & 487 \\
$4^{*}$ & 6.63 & 3.84 & .531 & 25.721 & 488 \\
\hline
\end{tabular}

the grains examined in this study (fig. 2). The presence of radial cracks corroborates significant concentrations of $U$ and Th within the crystal structure of these grains, and the development of this texture results from the physical ruin of the zirconolite grain through microfracturing due to volume expansion related to the $\alpha$-decay damage (Ewing 1999). These textures also denote $\alpha$-recoil tracks that create substantial damage to the crystal structure of the zirconolite, leading to brownish color, isotropization, and volume increase. As a consequence of this, the zirconolite grains expanded to crack the surrounding/host mineral (R. Gieré, pers. comm.). If the host rock is much older, this effect is more pronounced. An alternate mechanism for the formation of radial cracks is the expansion of zirconolite on phase transformation from a high-pressure polymorph to a low-pressure one during uplift. However, such a phase transformation process has not been verified in experiments. Although zirconolite grains are homogeneous, an alteration rim can be observed along the grain peripheries. The alteration product is similar in composition to the secondary materials (hydrous aluminium silicate) that fill the radial cracks. This type of radial crack is not visible around the baddeleyite grains apart from the presence of some minor microcracks with the grain.

The mineral chemistry of both zirconolite and baddeleyite (tables 1,2) suggests that they are highly depleted in REEs including $\mathrm{Y}$ but are enriched in actinide components. The zirconolite is enriched in $U$ and Th, with minor amounts of $\mathrm{Y}$. Baddeleyite also consists of considerable amounts of $\mathrm{Hf}$. $\mathrm{Zr}$ is common in both zirconolite and baddeleyite. The chemical characteristics of these two minerals observed in this study closely compare with those described from carbonatites (e.g., Purtscheller and Tessadri 1985; Bellatreccia et al. 1999) and from chromitites that were believed to have carbonatitic fluids derived from mantle (Zaccarini et al. 2004). While they sharply contrast with those reported, zirconolite and baddeleyite formed through late-stage hydrothermal processes or through metamorphism (Williams 1978; Gieré and Williams 1992; Zakrzewski et al. 1992; deHoog and van Bergen 2000; Della Ventura et al. 2000). Most of the late-stage crystallized zirconolite and baddeleyite are highly enriched in REEs, while those reported from carbonatites are characterized by higher amounts of actinides. The enrichment of "carbonatite-favored elements" such as U and Th, minor concentration of $\mathrm{Y}$ in zirconolite, prominent Hf component in baddeleyite, and lower abundance of REE in both zirconolite and baddeleyite all suggest that a melt/fluid with carbonatitic affinities was responsible for the formation of these rare accessory minerals (Purtscheller and Tessadri 1985; Bellatreccia et al. 1999; Zaccarini et al. 2004). We show the zirconolite compositions in a $\mathrm{Ca}^{2+}$. $(\mathrm{Th}+\mathrm{U})^{4+}-(\mathrm{REE}+\mathrm{Y})^{3+}$ diagram (fig. 7) that is widely used to discriminate zirconolite from diverse sources (e.g., de Hoog and van Bergen 1997, 2000; Zaccarini et al. 2004). The composition of all the analyzed zirconolite from the ACSZ falls within the carbonatite field. Hence, the mode of occurrence of zirconolite and baddeleyite and their

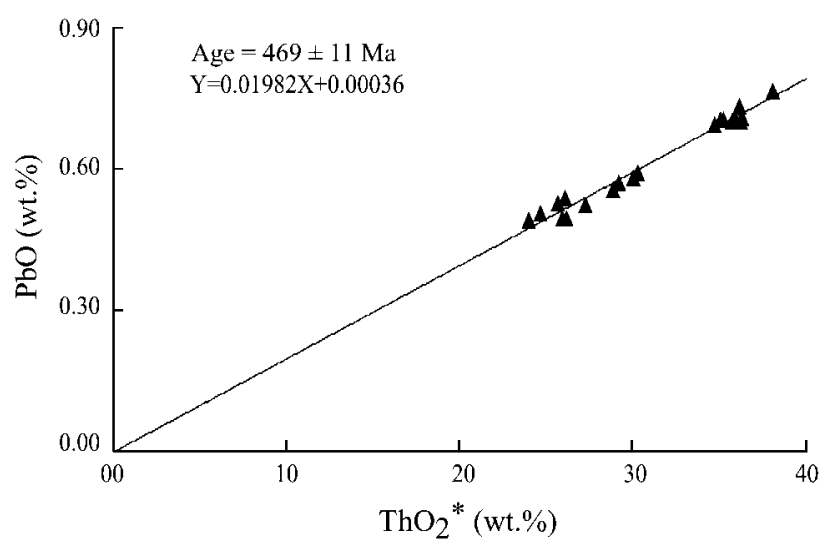

Figure 6. $\mathrm{PbO}$ versus $\mathrm{ThO}_{2}^{*}$ plot of zirconolite grains from phlogopite-graphite spinellite. The calculated linear age is also shown within the diagram. 


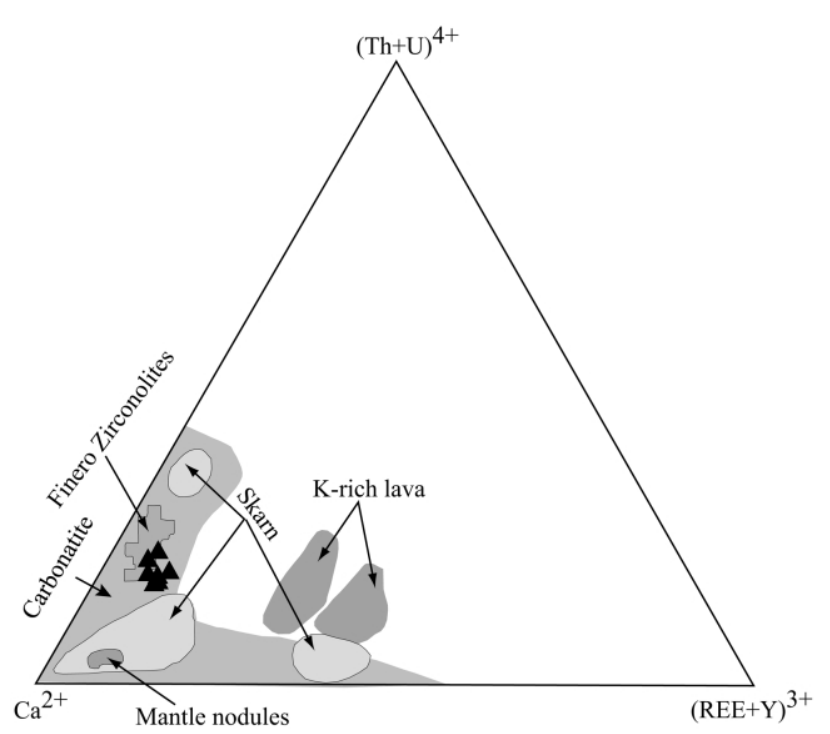

Figure 7. $\mathrm{Ca}^{2+}{ }_{-}(\mathrm{Th}+\mathrm{U})^{4+}-(\mathrm{REE}+\mathrm{Y})^{3+}$ diagram showing the composition of zirconolite from this study. The composition of Achankovil Shear Zone (ACSZ) zirconolite is compared with compositions of other zirconolites from carbonatites, metasomatic skarns (Williams and Gieré 1996), Finero zirconolites (Zaccarini et al. 2004), mantle nodules (Horning and Wörner 1991), and K-rich lavas (de Hoog and van Bergen 2000). The solid triangles represent zirconolite from the ACSZ.

mineral chemistry collectively suggest that these minerals are early crystallization products from a deep-seated melt that was supersaturated with $\mathrm{Ca}$, $\mathrm{Ti}, \mathrm{Zr}$, and other elements such as $\mathrm{Hf}, \mathrm{U}$, and $\mathrm{Th}$. We envisage a silica-undersaturated melt with possible carbonatitic affinity from a source that was markedly enriched with volatiles like $\mathrm{CO}_{2}$ and $\mathrm{H}_{2} \mathrm{O}$. Zaccarini et al. (2004) suggested a carbonatitetype metasomatism for the formation of zirconolite and other Zr-Th-U minerals such as baddeleyite, thorianite, and huttonite in the chromitites of the Finero complex, western Alps. They ascribed the formation of the carbonatite-type liquids/melts to the emplacement of mantle plumes at the base of the continental crust provoked by the pre-Hercynian period extensional tectonics. We infer a comparable scenario in this study where deep-seated extension along the ACSZ resulted in the generation of carbonatite-type melts.

Here we shall further consider in brief some of the characteristics of the ultramafic rocks that attribute carbonatitic signatures. The eastern part of the ultramafic intrusive is mainly composed of spinel dunite that contains dolomite and minor graphite. The dolomite in this rock is patchy in nature and is surrounded by late-stage serpentines (Rajesh et al. 2004). The ultramafic intrusive is highly enriched in graphite at the western part, and the presence of carbonate is limited there. The $\delta^{13} \mathrm{C}_{\mathrm{PDB}}$ values of $-7 \%$ to $-9 \%$ obtained from the carbonate minerals (Rajesh and Arima 2004) are similar to the $\delta^{13} \mathrm{C}_{\mathrm{PDB}}$ values of carbonates from primary carbonatites (Taylor et al. 1967). Carbon isotope compositions of the flaky graphite present throughout the ultramafic intrusive also possess mantle signatures (Rajesh 2004). The stable isotope values collectively indicate a deep-seated, juvenile mantle source for C. Graphite is also present as an included phase within olivine. Apart from these features, spinel from the ultramafic suite contains abundant inclusions of carbon in various forms such as pure $\mathrm{CO}_{2}$ fluid inclusions, graphite, and magnesite. We therefore infer that the melts responsible for the formation of these ultramafic intrusive were extremely rich in C (Rajesh et al. 2004) and other alkaline-carbonatite components.

The localized variations of oxygen fugacity also played a major role in the crystallization of zirconolite and baddeleyite (Cuney and Friedrich 1987; Gieré et al. 1998; Zaccarini et al. 2004). In this study, the zirconolite was found associated with ultramafic units that are enriched in graphite toward the western part of the intrusive, whereas baddeleyite occurs toward the central part, where abundant dolomite and calcite are noticed in spinel dunite and phlogopite dunite. The coexistence of graphite-magnesite and $\mathrm{CO}_{2}$-graphite inclusions within the spinel is also indicative of localized variations of oxygen fugacity that might have occurred during the crystallization of these rocks. Della Ventura et al. (2000) proposed that the total amount of actinide and REE accommodation within a zirconolite structure is mainly a function of the redox conditions that existed at the time of its formation. An increase in oxygen fugacity may lead to precipitation of baddeleyite from the melts supersaturated with $\mathrm{Zr}$ under extremely low silica activities (Bingen et al. 2001; Dawson et al. 2001).

Gieré et al. (1998) and Stucki et al. (2001) proposed that the chemical characteristics of zirconolite in general imitate the common chemical characteristics of the host rocks, especially in terms of trace elements. Dawson et al. (2001) concluded that high $\mathrm{Ca}$ and low Si favor baddeleyite formation. The $\mathrm{Ca}$ required for the formation of zirconolite may have been introduced by a melt that was amply saturated with $\mathrm{ZrO}_{2}$ relative to $\mathrm{CaO}$ and $\mathrm{TiO}_{2}$ (Dawson et al. 2001). These minerals are the zirconium-rich mineral phases that are commonly found in many carbonatites (Raber and Haggerty 
1979; Bellatreccia et al. 1999; Lumpkin 1999). In addition, the chemical composition of the zirconolite and baddeleyite from the ACSZ are also closely comparable to those reported from carbonatites (Purtscheller and Tessadri 1985; Bellatreccia et al. 1999; Zaccarini et al. 2004). Hence we reasonably conclude that elements commonly found in carbonatite magmas such as $\mathrm{C}, \mathrm{Ca}, \mathrm{Zr}, \mathrm{U}$, and $\mathrm{Th}$ were responsible for the formation of zirconolite and baddeleyite in the ACSZ ultramafic suite under high $\mathrm{CO}_{2}$ activities and localized variation in oxygen fugacity level. The $\delta^{13} \mathrm{C}$ isotopic signatures of dolomite and graphite that correspond to mantle values, presence of pure $\mathrm{CO}_{2}$ fluid inclusions, graphite and magnesite mineral inclusions in spinel, and crystallization of baddeleyite and zirconolite in these rocks together point toward a carbonatitic source. The presence of zirconolite and baddeleyite further confirms the mobility of usually immobile elements such as $\mathrm{Zr}, \mathrm{REE}$, and $\mathrm{Ti}$ along this shear zone. The moderate amounts of $\mathrm{F}$ (1.3-1.5 wt\%) detected in phlogopite (Rajesh et al. 2004) can accelerate the mobilization of these high field strength elements (de Hoog and van Bergen 2000). On the basis of all these lines of evidence, this is the first report of mantle-derived rocks with carbonatitic affinity from the ACSZ.

Age Constraints and Tectonic Implications. The timing of crystallization of the zirconolite within the ultramafic suite is confined to be early Ordovician (mean age $469 \pm 11 \mathrm{Ma}$ ), which marks the closure temperature of the U-Pb system within this mineral following the emplacement of the host spinellite. Within the limits of accuracy of the ages $( \pm 11 \mathrm{Ma})$, the data from these grains are chronologically homogeneous and are analogous to the ages obtained from phlogopites in dunite and glimmerite (Rajesh et al. 2004) using K-Ar dating (mean age $468 \pm 9 \mathrm{Ma}$ ). Closure temperature of the U-Pb system is different in various minerals, ranging from $>800^{\circ} \mathrm{C}$ in zircon (Watson and Harrison 1983) and $>550^{\circ} \mathrm{C}$ in titanite (Rollinson 1993), while that of $\mathrm{Ar}$ in phlogopite is estimated as $415^{\circ} \pm 40^{\circ} \mathrm{C}$ (Garnier et al. 2002). The broadly overlapping ages from $\mathrm{U}-\mathrm{Pb}$ in zirconolite and $\mathrm{K}-\mathrm{Ar}$ in phlgopite may indicate that either the cooling rate was extremely rapid or the closure temperature for the U-Pb system in zirconolite is markedly low. The age data presented here also preclude the possibility that the zirconolites are inherited from the surrounding granulite facies metamorphic rocks or felsic intrusives (granites), which have all yielded Pan-African ages for the peak thermal event.

Early to late Ordovician ages have also been recorded from the rim part of many monazites from the metapelites and charnockites of the TB and ACSZ (Braun et al. 1998; Santosh et al. 2003, 2005a). Braun and Bröcker (2004) also identified Ordovician age populations in leucogranites of the TB on the basis of EPMA monazite ages. Some studies speculated this period as the time of retrogressive fluid flow in the ACSZ and the adjacent TB. These ages are considerably younger than the widespread peak Pan-African metamorphism, magmatism, and felsic intrusions in the ACSZ. However, the cluster of Ordovician ages obtained in some of these reports as well as this study raises the vital question of the significance of these ages. While it would require careful geochronologic studies in the future to identify the orogenic link of this thermal anomaly, we make a brief attempt here to evaluate the phlogopite ages in terms of regional correlation. In a recent study (Miyazaki and Santosh 2005), K-Ar ages of 445-454 Ma were obtained from an alkali syenite at Puttetti emplaced at the boundary between the TB and NB, farther south of this study area. Miyazaki et al. (1997, 2001) determined phlogopite-whole rock $\mathrm{Rb}-\mathrm{Sr}$ isochron ages from the Eppawala carbonatite complex in Sri Lanka and obtained ages of $447 \pm 2 \mathrm{Ma}$. Weerakoon et al. (2001) determined Rb-Sr biotite-apatite-whole rock ages from the Eppawala carbonatite body and obtained an age of $493 \pm 5 \mathrm{Ma}$. Rakotondrazafy et al. (1997) reported K-Ar ages in the range of 491$485 \mathrm{Ma}$ for phlogopite mineralization in southern Madagascar. Phlogopite mineralization in southern India, Sri Lanka, and Madagascar thus spans a common age in the range of 445-493 Ma. The common age range for phlogopites in the three adjacent crustal fragments within the Gondwana assembly may indicate a common tectonothermal event and phlogopite mineralization during the Ordovician.

In summary, we interpret the early Ordovician ages obtained in this study to coincide with the timing of extensional collapse of the orogen following the collisional assembly of the Gondwana supercontinent in the latest Neoproterozoic-Cambrian times. The occurrence of the ultramafic suite within the central domain of the ACSZ suggests the possibility that this transcrustal lineament is a mantle-rooted weak structure that provided the pathway for emplacement of the ultramafic magmas that were ultimately tapped from carbonatitic mantle sources. The elongation direction of the ultramafic suite disposed parallel to the trend of the ACSZ also suggests a structurally controlled emplacement under rift-related settings. 


\section{A C K N O W L E D G M E N T S}

V. J. Rajesh acknowledges a doctoral fellowship from the Japanese Ministry of Education, Sports, Culture, Science, and Technology and thanks Y. Tsutsumi and M. Shigeoka (National Science Museum, Tokyo, Japan) for their valuable assistance in EPMA analysis. V. J. Rajesh is thankful to Reto Gieré (Mineralogisch-Geochemisches Institut, Freiburg, Germany) for personal discussions during several stages of this work. M. Santosh thanks Kochi University, Kochi, Japan, for facilities and support. This work has benefited greatly from the constructive reviews of S. E. Haggerty and F. Zaccarini.
This is a contribution to the Grant-in-Aid for Scientific Research provided by the Japanese Society for the Promotion of Science to M. Arima (Yokohama National University, Yokohama, Japan; 13373005 and 12440147), Grant-in-Aid from the Japanese Ministry of Education, Sports, Culture, Science, and Technology to M. Santosh (17403013), and a grant to V. J. Rajesh from the postdoctoral program of Chonbuk National University, Chonbuk, South Korea (2004). This study was also supported by a Grants-in-Aid (2005-1047-900011) from the Korea Science and Engineering Foundation. This work is also a contribution to IGCP 368,440 , and 453.

\section{REFERENCES CITED}

Bartlett, J. M.; Dougherty-Page, J. S.; Harris, N. B. W.; Hawkesworth, C. J.; and Santosh, M. 1998. The application of single zircon evaporation and model $\mathrm{Nd}$ ages to the interpretation of polymetamorphic terrains: an example from the Proterozoic mobile belt of south India. Contrib. Mineral. Petrol. 131:181-195.

Bayliss, P.; Mazzi, F.; Munno, R.; and White, T. J. 1989. Mineral nomenclature: zirconolite. Mineral. Mag. 53: 565-569.

Bellatreccia, F.; Della Ventura, D. G.; Caprilli, E.; Williams, C. T.; and Parodi, G. C. 1999. Crystal-chemistry of zirconolite and calzirite from Jacupiranga, São Paulo (Brazil). Mineral. Mag. 63:649-660.

Biju-Sekhar, S.; Yokoyama, K.; Pandit, M. K.; Okudaira, T.; Yoshida, M.; and Santosh, M. 2003. Late Paleoproterozoic magmatism in Delhi Fold Belt, NW India and its implication: evidence from EPMA chemical ages of zircons. J. Asian Earth Sci. 22:189-207.

Bindu, R. S.; Suzuki, K.; Yoshida, M.; and Santosh, M. 1998. The first report of CHIME monazite age from the south Indian granulite terrain. Curr. Sci. 74:852858.

Bingen, B.; Austrheim, H.; and Whitehouse, M. 2001. Ilmenite as a source for zirconium during high-grade metamorphism? textural evidence from the Caledonides of western Norway and implications for zircon geochronology. J. Petrol. 42:355-375.

Borodin, L. S.; Nazarenko, I. I.; and Richter, T. L. 1957. On a new mineral zirconolite: a complex oxide of $\mathrm{AB}_{3} \mathrm{O}_{7}$ type. Am. Mineral. 42:581-582.

Brandon, A. D., and Meen, J. K. 1995. Nd isotopic evidence for the position of southernmost Indian terranes within East Gondwana. Precambrian Res. 70:269-280.

Braun, I., and Bröcker, M. 2004. Monazite dating of granitic gneisses and leucogranites from the Kerala Khondalite Belt, southern India: implications for Late Proterozoic crustal evolution in East Gondwana. Int. J. Earth Sci. (Geol. Rundsch.) 93:13-22.

Braun, I., and Kriegsman, L. M. 2003. Proterozoic crustal evolution of southernmost India and Sri Lanka. In Yoshida, M.; Windley, B. F.; and Dasgupta, S., eds. Pro- terozoic East Gondwana: supercontinent assembly and breakup. Geol. Soc. Lond. Spec. Publ. 206:169202.

Braun, I.; Montel, J.-M.; and Nicollet, C. 1998. Electron microprobe dating of monazites from high-grade gneisses and pegmatites of the Kerala Khondalite Belt, southern India. Chem. Geol. 146:65-85.

Bulakh, A. G.; Nesterov, A. R.; Williams, C. T.; and Anisimov, I. S. 1998. Zirkelite from the Sebl'yavr carbonatite complex, Kola Peninsula, Russia: an x-ray and electron microprobe study of a partially metamict mineral. Mineral. Mag. 62:837-846.

Carlier, G., and Lorand, J.-P. 2003. Petrogenesis of a zirconolite-bearing Mediterranean-type lamproite from the Peruvian Altiplano (Andean Cordillera). Lithos 69:15-35.

Cenki, B.; Braun, I.; and Bröcker, M. 2004. Evolution of the continental crust in the Kerala Khondalite Belt, southernmost India: evidence from $\mathrm{Nd}$ isotope mapping combined with $\mathrm{U}-\mathrm{Pb}$ and $\mathrm{Rb}-\mathrm{Sr}$ geochronology. Precambrian. Res. 134:275-292.

Choudhary, A. K.; Harris, N. B. W.; Van Calsteren, P.; and Hawkesworth, C. J. 1992. Pan-African charnockite formation in Kerala, south India. Geol. Mag. 129:257264.

Collins, A. S., and Santosh, M. 2004. New protolith provenance, crystallisation and metamorphic $\mathrm{U}-\mathrm{Pb}$ zircon SHRIMP ages from southern India. In Chetty, T. R. K., and Bhaskar Rao, Y. J., eds. International field workshop on the Southern Granulite Terrane. Hyderabad, India, National Geophysical Research Institute, p. $73-76$.

Cuney, M., and Friedrich, M. 1987. Physicochemical and crystal-chemical controls on accessory mineral paragenesis in granitoids: implications for uranium metallogenesis. Bull. Mineral. 110:235-247.

Dawson, J. B.; Hill, P. G.; and Kinny, P. D. 2001. Mineral chemistry of a zircon-bearing, composite, veined and metasomatised upper-mantle peridotite xenolith from kimberlite. Contrib. Mineral. Petrol. 140:720-733.

de Hoog, J. C. M., and van Bergen, M. J. 1997. Notes on 
the chemical composition of zirconolite with thorutite inclusions from Walaweduwa, Sri Lanka. Mineral. Mag. 61:721-725.

2000. Volatile-induced transport of HFSE, REE, $T h$ and $U$ in arc magmas: evidence from zirconolitebearing vesicles in potassic lavas of Lewotolo volcano (Indonesia). Contrib. Mineral. Petrol. 139:485-502.

Della Ventura, D. G.; Bellatreccia, F.; and Williams, C. T. 2000. Zirconolite with significant REE $\mathrm{ZrNb}(\mathrm{Mn}, \mathrm{Fe}) \mathrm{O}_{7}$ from a xenolith of the Laacher See eruptive center, Eifel Volcanic Region, Germany. Can. Mineral. 38:57-65.

Drury, S. A., and Holt, R. W. 1980. The tectonic framework of the south Indian craton: a reconnaissance involving LANDSAT imagery. Tectonophysics 65:T1T5.

Ewing, R. C. 1999. Nuclear waste forms for actinides. Proc. Natl. Acad. Sci. USA 96:3432-3439.

Garnier, V.; Giuliani, G.; Maluski, H.; Ohnenstetter, D.; Trong, T. P.; Quang, V. H.; Van, L. P.; Van, T. V.; and Schwarz, D. 2002. Ar-Ar ages in phlogopites from marble-hosted ruby deposits in northern Vietnam: evidence for Cenozoic ruby formation. Chem. Geol. 188: 33-49.

Gieré, R. 1986. Zirconolite, allanite and hoegbomite in a marble skarn from the Bergell contact aureole: implication for mobility of $\mathrm{Ti}, \mathrm{Zr}$ and REE. Contrib. Mineral. Petrol. 93:459-470.

Gieré, R., and Williams, C. T. 1992. REE-bearing minerals in a Ti-rich vein from the Adamello contact aureole (Italy). Contrib. Mineral. Petrol. 112:83-100.

Gieré, R.; Williams, C. T.; and Lumpkin, G. R. 1998. Chemical characteristics of natural zirconolite. Schweiz. Mineral. Petrogr. Mitt. 78:433-459.

Harley, S. L. 1994. Mg-Al yttrian zirconolite in a partially melted sapphirine granulite, Vestfold Hills, East Antarctica. Mineral. Mag. 58:259-269.

Harris, N. B. W.; Bartlett, J. M.; and Santosh, M. 1996. Neodymium isotope constraints on the tectonic evolution of East Gondwana. J. Southeast Asian Earth Sci. 14:119-125.

Harris, N. B. W.; Santosh, M.; and Taylor, P. N. 1994. Crustal evolution in south India: constraints from $\mathrm{Nd}$ isotopes. J. Geol. 102:139-150.

Heaman, L. M., and LeCheminant, A. N. 1993. Paragenesis and $\mathrm{U}-\mathrm{Pb}$ systematics of baddeleyite $\left(\mathrm{ZrO}_{2}\right)$ Chem. Geol. 110:95-126.

- 2000. Anomalous U-Pb systematics in mantlederived baddeleyite xenocrysts from Île Bizard: evidence for high temperature radon diffusion? Chem. Geol. 172:77-93.

Horning, I., and Wörner, G. 1991. Zirconolite-bearing ultrapotassic veins in a mantle xenolith from Mt. Melbourne Volcanic Field, Victoria Land, Antarctica. Contrib. Mineral. Petrol. 106:355-366.

Kerschhofer, L.; Scharer, U.; and Deutsch, A. 2000. Evidence for crystals from the lower mantle: baddeleyite megacrysts of the Mbuji Mayi kimberlite. Earth Planet. Sci. Lett. 179:219-225.

Lumpkin, G. R. 1999. Physical and chemical characteristics of baddeleyite (monoclinic zirconia) in natural environments: an overview and case study. J. Nucl. Mater. 274:206-217.

Mazzi, F., and Munno, R. 1983. Calciobetafite (new mineral of the pyrochlore group) and related minerals from Campi Flegrei, Italy: crystal structures of polymignyte and zirkelite: comparison with pyrochlore and zirconolite. Am. Mineral. 68:262-276

Miyazaki, T.; Kagami, H.; Shuto, K.; and Morikiyo, T. 1997. Geochronological geochemical characterization of some alkaline plutons from Tamil Nadu, South India: implications for the Pan-African Orogeny. Gondwana Res. 1:154.

Miyazaki, T.; Morikiyo, T.; Weerakoon, M. W. K.; Kagami, H.; and Dahanayake, K. 2001. Geochemical characteristics of the Eppawala Carbonatite Body, Sri Lanka: limestone assimilation by carbonatitic magma. Proc. 1st International Symposium Isotopomers (Yokohama, 2001), p. 321-322.

Miyazaki, T., and Santosh, M. 2005. Cooling history of the Puttetti alkali syenite pluton, southern India. Gondwana Res. 8:567-574.

Montel, J. M.; Foret, S.; Veschambre, M.; Nicollet, C.; and Provost, A. 1996. Electron microprobe dating of monazite. Chem. Geol. 131:37-53.

Morimoto, T.; Santosh, M.; Tsunogae, T.; and Yoshimura, Y. 2004. Spinel + quartz association from the Kerala khondalites, southern India: evidence for ultrahightemperature metamorphism. J. Mineral. Petrol. Sci. 99:257-278.

Nandakumar, V., and Harley, S. L. 2000. A reappraisal of the pressure temperature path of granulites from the Kerala Khondalite Belt, southern India. J. Geol. 108: 687-703.

Purtscheller, F., and Tessadri, R. 1985. Zirconolite and baddeleyite from metacarbonates of the Oetztal-Stubai complex (northern Tyrol, Austria). Mineral. Mag. 49:523-529.

Raber, E., and Haggerty, S. E. 1979. Zircon-oxide reactions in diamond-bearing kimberlites. In Boyd, F. R., and Meyer, H. O. A., eds. Kimberlites, diatremes, and diamonds: their geology, petrology and geochemistry. Proc. Second International Kimberlite Conference 1: 229-240.

Raith, M.; Karmakar, S.; and Brown, M. 1997. Ultra-hightemperature metamorphism and multistage decompressional evolution of sapphirine granulites from the Palni Hills Ranges, southern India. J. Metamorph. Geol. 15:379-399.

Rajaram, M.; Harikumar, P.; and Brown, M. 2003. Thin magnetic crust in the Southern Granulite Terrane. In Ramakrishnan, M., ed. Tectonics of Southern Granulite Terrane. Geol. Soc. India Mem. 50:165-176.

Rajesh, H. M.; Santosh, M.; and Yoshida, M. 1998. Dextral Pan-African shear along the southwestern edge of the Achankovil Shear Belt, south India: constraints on Gondwana reconstructions: a discussion. J. Geol. 106: 105-109.

Rajesh, V. J. 2004. Graphite-dolomite-phlogopite bearing ultramafic rocks in Achankovil Shear Zone, south India: implications for highly potassic carbon-rich fluid 
influx along an intra-continental shear zone. $\mathrm{PhD}$ dissertation, Yokohama National University, Japan.

Rajesh, V. J., and Arima, M. 2004. Dolomite-phlogopite bearing ultramafic rocks in Achankovil Shear Zone, south India and its implications for deep rooted fluid activity and crust mantle interactions. In Chetty, $\mathrm{T}$. R. K., and Bhaskar Rao, Y. J., eds. International field workshop on the Southern Granulite Terrane. Hyderabad, India, National Geophysical Research Institute, p. 92-93.

Rajesh, V. J.; Arima, M.; and Santosh, M. 2004. Dunite, glimmerite and spinellite in Achankovil Shear Zone, south India: highly potassic $\mathrm{CO}_{2}$-rich melt influx along an intra-continental shear zone. Gondwana Res. 7:961-974.

Rakotondrazafy, R.; Pierdzig, S.; Raith, M.; and Hoernes, S. 1997. Phlogopite-mineralizations in the Beraketa belt of southern Madagascar: a spectacular example of channelised fluid flow and fluid-rock interaction. Gondwana Res. Group Misc. Publ. 5:81-82.

Rasmussen, B., and Fletcher, I. R. 2004. Zirconolite: a new U-Pb chronometer for mafic igneous rocks. Geology 32:785-788.

Ringwood, A. E.; Kesson, S. E.; War, N. G.; Hibberson, W.; and Major, A. 1979. Immobilisation of high level nuclear reactor wastes in SYNROC. Nature 278:219223.

Rollinson, H. R. 1993. Using geochemical data: evaluation, presentation, interpretation. London, Longman, $352 \mathrm{p}$.

Sacks, P. E.; Nambiar, G. G.; and Walters, L. J. 1997. Dextral Pan-African shear along the southwestern edge of the Achankovil Shear Belt, south India: constraints on Gondwana reconstructions. J. Geol. 105: 275-284.

Sajeev, K.; Osanai, Y.; and Santosh, M. 2004. Ultrahigh temperature metamorphism of sapphirine-bearing granulites from Ganguvarpatti, southern India. Contrib. Mineral. Petrol. 148:29-46.

Sandiford, M., and Santosh, M. 1991. A granulite facies kalsilite-leucite-hibonite association from Punalur, southern India. Mineral. Petrol. 43:225-236.

Santosh, M. 1987. Cordierite gneisses of South Kerala, India: petrology, fluid inclusions and implications on uptlift history. Contrib. Mineral. Petrol. 97:343-356.

- 1996. The Trivandrum and Nagercoil granulite blocks. In Santosh, M., and Yoshida, M., eds. The Archean and Proterozoic terrains of southern India within East Gondwana. Gondwana Res. Group Mem. 3:243-277.

Santosh, M.; Collins, A. S.; Morimoto, T.; and Yokoyama, K. 2005a. Depositional constraints and age of metamorphism in southern India: U-Pb chemical (EMPA) and isotopic (SIMS) ages from the Trivandrum Block. Geol. Mag. 142:1-14.

Santosh, M.; Kagami, H.; Yoshida, M.; and Nanda Kumar, V. 1992. Pan-African charnockite formation in East Gondwana: geochronologic (Sm-Nd and $\mathrm{Rb}-\mathrm{Sr}$ ) and petrogenetic constraints. Bull. Ind. Geol. Assoc. 25:110.
Santosh, M.; Tanaka, K.; Yokoyama, Y.; and Collins, A. S. 2005b. Late Neoproterozoic-Cambrian felsic magmatism along transcrustal shear zones in southern India: U-Pb electron microprobe ages and implications for the amalgamation of the Gondwana supercontinent. Gondwana Res. 8:31-42.

Santosh, M.; Yokoyama, K.; Biju-Sekhar, S.; and Rogers, J. J. W. 2003. Multiple tectonothermal events in the granulite blocks of southern India revealed from EPMA dating: implications on the history of supercontinents. Gondwana Res. 6:29-63.

Scoates, J. S., and Chamberlain, K. R. 1995. Baddeleyite $\left(\mathrm{ZrO}_{2}\right)$ and zircon $\left(\mathrm{ZrSiO}_{4}\right)$ from anorthositic rocks in the Laramie anorthosite complex, Wyoming: petrologic consequences and U-Pb ages. Am. Mineral. 80: 1319-1329.

Soman, K.; Nair, N. G. K.; Golubyev, V. N.; and Arakdyan, M. M. 1982. Age data on pegmatites of south Kerala and their tectonic significance. J. Geol. Soc. India 23:458-462.

Soman, K.; Santosh, M.; and Golubyev, V. N. 1983. Early Paleozoic I-type granite from central Kerala and its bearing on possible mineralisation. Indian J. Earth Sci. 10:137-141.

Stucki, A.; Trommsdorff, V.; and Gunther, D. 2001. Zirconolite in metarodingites of Penninic Mesozoic ophiolites, Central Alps. Schweiz. Mineral. Petrogr. Mitt. 81:257-265.

Suzuki, K., and Adachi, M. 1991. Precambrian provenance and Silurian metamorphism of the Tsubonosawa paragneiss in the South Kitakami Terrane, northeast Japan, revealed by the chemical Th-U-total $\mathrm{Pb}$ isochron ages of monazite, zircon and xenotime. Geochem. J. 25:357-376.

- 1994. Middle Precambrian detrital monazite and zircon from the Hida gneiss on Oki-Dogo Island, Japan: their origin and implications for the correlation of basement gneiss of southwest Japan and Korea. Tectonophysics 235:277-292.

Suzuki, K.; Adachi, M.; and Tanaka, T. 1991. Middle Precambrian provenance of Jurassic sandstone in the Mino Terrane, central Japan: Th-U-total $\mathrm{Pb}$ evidence from an electron microprobe monazite study. Sediment. Geol. 75:141-147.

Tateishi, K.; Tsunogae, T.; Santosh, M.; and Janardhan, A. S. 2004. First report of sapphirine + quartz assemblage from southern India: implications for ultrahightemperature metamorphism. Gondwana Res. 7:899912.

Taylor, H. P.; Frechen, J.; and Degens, E. T. 1967. Oxygen and carbon isotope studies of carbonatites from the Laacher Sea district, West Germany and the Alnö district, Sweden. Geochim. Cosmochim. Acta 31:407430.

Tropper, P.; Rhede, D.; and Bernhard, F. 2003. Trace element mobility in contact metamorphic rocks from the Austroalpine basement: baddeleyite-zirconolite (-zircon) veins in marbles from the Stubenberg granite contact aureole (Styria, Austria). Geophys. Res. Abstr. 5:02236. 
Watson, E. B., and Harrison, M. T. 1983. Zircon saturation revisited: temperature and composition effects in a variety of crustal magma types. Earth Planet. Sci. Lett. 64:295-304.

Weerakoon, M. W. K.; Miyazaki, T.; Shuto, K.; and Kagami, H. 2001. Rb-Sr and Sm-Nd geochronology of the Eppawala metamorphic rocks and carbonatite, Wanni Complex, Sri Lanka. Gondwana Res. 4:409-420.

Williams, C. T. 1978. Uranium-enriched minerals in mesostasis areas of the Rhum layered pluton. Contrib. Mineral. Petrol. 66:29-39.

Williams, C. T., and Gieré, R. 1996. Zirconolite: a review of localities worldwide, and a compilation of its chemical compositions. Bull. Nat. Hist. Mus. Lond. (Geol.) 52:1-24.

Windley, B. F.; Razafiniparany, A.; Razakamana, T.; and Ackermand, D. 1994. Tectonic framework of the Pre- cambrian of Madagascar and its Gondwana connections: a review and reappraisal. Geol. Rundsch. 83: 642-659.

Yokoyama, K., and Zhou, B. 2002. Preliminary study of ages of monazites in sands from the Yangtze River. Natl. Sci. Mus. Monogr. 22:83-88.

Zaccarini, F.; Stumpfl, E. F.; and Garuti, G. 2004. Zirconolite and Zr-Th-U minerals in chromitites of the Finero complex, western Alps, Italy: evidence for carbonatite-type metasomatism in a subcontinental mantle plume. Can. Mineral. 42:1825-1845.

Zakrzewski, M. A.; Lustenhouwer, W. J.; Nugteren, H. J.; and Williams, C. T. 1992. Rare-earth minerals yttrian zirconolite and allanite-(Ce) and associated minerals from Koberg mine, Bergslagen, Sweden. Mineral. Mag. 56:27-35. 